\title{
Blanching effect on the bioactive compounds and on the viability of Lactobacillus rhamnosus GG before and after in vitro simulation of the digestive system in jabuticaba juice
}

\section{Efeito do branqueamento nos compostos bioativos e na viabilidade de Lactobacillus rhamnosus GG antes e após simulação in vitro do sistema digestivo em suco de jabuticaba}

\author{
Daniane Campos de Oliveira ${ }^{1}$; Eliane Maurício Furtado Martins²; \\ Maurilio Lopes Martins²*; Giovanna Bretas Martins ${ }^{1}$; Mirella Lima Binoti³; \\ André Narvaes da Rocha Campos ${ }^{2}$; Afonso Mota Ramos ${ }^{4}$; \\ Maurício Henriques Louzada Silva²; Paulo César Stringheta ${ }^{4}$
}

\begin{abstract}
The viability of Lactobacillus rhamnosus GG (LGG) in jabuticaba juices and its survival in the gastrointestinal tract (GIT), simulated in vitro, was studied. Two juices were prepared: A - with nonblanched fruits, and B - with blanched fruits. LGG was then added and the juices maintained at 8 ${ }^{\circ} \mathrm{C}$ for 28 days. The control treatment consisted of juices without the added probiotic. The following were determined in the juices: the viability and in vitro survival of LGG, fecal coliforms, Salmonella sp., $\mathrm{pH}$, acidity, total soluble solids (TSS), color, antioxidant capacity, total phenolic compounds, anthocyanins and ascorbic acid. The sensory acceptability was also determined using a 9-point hedonic scale. Blanching interfered $(p<0.05)$ with the viability of LGG, juice A showing the greatest viability as compared to juice B. After in vitro simulation, the probiotic bacterial count was $<1.0 \log \mathrm{CFU} \mathrm{mL}^{-1}$, which demonstrates the low resistance of the strain to the simulated GIT conditions. The juices were conformed to the microbiological standards established by law. The $\mathrm{pH}$, acidity and TSS were influenced by blanching $(\mathrm{p}<0.05)$, with values of $5.03,0.46 \%$ and $15.38^{\circ}$ Brix for juice $A$ and $5.12,0.66 \%$ and 16.05 ${ }^{\circ}$ Brix for juice B, respectively. The addition of LGG did not influence these characteristics. Only the $\mathrm{pH}$ value was influenced by the storage time $(\mathrm{p}<0.05)$, increasing throughout storage. Juice B showed lower luminosity $\left(\mathrm{L}^{*}\right)$ and a greater value for $\mathrm{a}^{*}$ as compared to juice $\mathrm{A}$, indicating that the former became darker and redder due to the blanching process. Both juices showed positive values for the $\mathrm{b}^{*}$ coordinate. The juice was found to be a good source of polyphenols. Neither the time nor the addition of LGG affected the antioxidant capacity, total phenolic compounds or anthocyanin contents. However, blanching contributed $(\mathrm{p}<0.05)$ to an increase in the contents of these compounds in the juices. Values for antioxidant capacity of 186.20 and $2552.59 \mathrm{uM}$ Trolox g $^{-1}$, for total phenolic compounds of 275.06 and $1163.18 \mathrm{mg}$ GAE $100 \mathrm{~g}^{-1}$-wwb, and for anthocyanins as cyanidin 3-glucoside of 12.71 and $90.99 \mathrm{mg}$

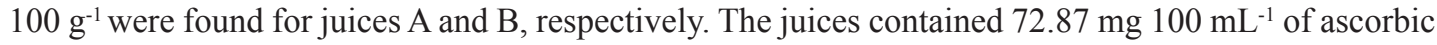
acid. Scores of above 6.0 (liked slightly) were awarded on the hedonic scale for the attributes evaluated. The addition of probiotics in jabuticaba juices needs to be further studied to ensure the viability of the cultures during storage and their survival in the gastrointestinal tract.
\end{abstract}

Key words: Blanching. Jabuticaba. New product. Probiotic.

\footnotetext{
${ }^{1}$ Discentes, Curso de Mestrado, Programa de Pós-graduação em Ciência e Tecnologia de Alimentos, Instituto Federal do Sudeste de Minas Gerais, IF Sudeste MG, Rio Pomba, MG, Brasil E-mail: daniane.campos@ifsudestemg.edu.br; bretasgiovanna@gmail. com

2 Profs., Instituto Federal do Sudeste de Minas Gerais, IF Sudeste MG, Rio Pomba, MG, Brasil E-mail: eliane.martins@ifsudestemg. edu.br; maurilio.martins@ifsudestemg.edu.br; andre.campos@ifsudestemg.edu.br; mauricio.louzada@ifsudestemg.edu.br

${ }^{3}$ Prof $^{a}$, Universidade Federal de Juiz de Fora, UFJF, Juiz de Fora, MG, Brasil. E-mail: mirella.binoti@ufjf.edu

${ }^{4}$ Profs., Universidade Federal de Viçosa, UFV, Viçosa, MG, Brasil. E-mail: amramos@ufv.br; pstringheta@gmail.com

* Author for correspondence
} 


\section{Resumo}

A viabilidade de Lactobacillus rhamnosus GG (LGG) em sucos de jabuticaba e sua sobrevivência ao trato gastrointestinal (TGI) simulado in vitro foram estudadas. Foram preparados dois sucos: A (com frutas não branqueadas) e B (com frutas branqueadas), os quais foram adicionados de LGG e mantidos a $8^{\circ} \mathrm{C}$ durante 28 dias. $\mathrm{O}$ tratamento controle consistiu dos sucos sem adição de probiótico. Determinouse a viabilidade e a sobrevivência in vitro de LGG nos sucos, coliformes termotolerantes, Salmonella sp., pH, acidez, sólidos solúveis totais (SST), cor, capacidade antioxidante, compostos fenólicos totais, antocianinas totais e ácido ascórbico, além da aceitabilidade em escala hedônica de 9 pontos. O branqueamento interferiu $(\mathrm{p}<0,05)$ na viabilidade de LGG, sendo que o suco A apresentou maior viabilidade desta bactéria comparado ao suco $\mathrm{B}$. A contagem de LGG após a simulação da sobrevivência in vitro foi $<1,0 \log$ UFC $\mathrm{mL}^{-1}$ estimado, demonstrando a baixa resistência da estirpe às condições do TGI simulado quando veiculado pelos sucos de jabuticaba. Os sucos atenderam aos padrões microbiológicos estabelecidos pela legislação. $\mathrm{O}$ pH, acidez e SST dos sucos foram influenciados pelo branqueamento $(\mathrm{p}<0,05)$, sendo os valores médios de 5,03, 0,46\%, 15,38 ${ }^{\circ}$ Brix para os sucos A e $5,12,0,66 \%$ e $16,05{ }^{\circ}$ Brix para os sucos $\mathrm{B}$, respectivamente. A adição do probiótico não influenciou estas características $(p>0,05)$. Os sucos $B$ apresentaram menor luminosidade $\left(L^{*}\right)$ e maior valor de a* com coloração mais escura e avermelhada. Ambos os sucos apresentaram valores positivos para a coordenada $b^{*}$. Os sucos revelaram ser fonte de compostos fenólicos como antocianinas, responsáveis pela considerável capacidade antioxidante dos produtos. Não foi observado efeito do tempo e da adição de LGG na capacidade antioxidante, compostos fenólicos totais e antocianinas. Entretanto, o branqueamento contribuiu $(\mathrm{p}<0,05)$ para elevar o teor desses compostos nos sucos. Constatou-se 186,20 e $2.552,59 \mu \mathrm{M}$ Trolox g ${ }^{-1}$ de capacidade antioxidante, 275,06 e 1.163,18 mg AGE $100 \mathrm{~g} \mathrm{~g}^{-1}$ bu de fenólicos totais e 12,71 e $90,99 \mathrm{mg}$ de cianidina-3-glucosideo $100 \mathrm{~g}^{-1}$ para os sucos A e B, respectivamente. Os sucos apresentaram $72,87 \mathrm{mg} 100 \mathrm{~mL}^{-1}$ de ácido ascórbico. Foram atribuídas notas acima de 6,0 (gostei ligeiramente) na escala hedônica de 9 pontos para os atributos avaliados. A adição de probióticos em suco de jabuticaba necessita ser mais estudada para garantir a viabilidade das culturas durante a estocagem e a sobrevivência ao TGI.

Palavras-chave: Branqueamento. Jabuticaba. Novo produto. Probiótico.

\section{Introduction}

The majority of the probiotic products available for consumption are commercialized in the form of yogurts and fermented milks. Although these fermented dairy products are good matrixes for carrying probiotic microorganisms, other matrixes of vegetable origin have been studied and have shown promising potential (KUMAR et al., 2015; MARTINS et al., 2015a; PERES et al., 2012), considering the increase in vegetarianism, and the elevated number of hypercholesterolemic and lactose intolerant individuals. Thus an increase in the inclusion of probiotic microorganisms in commercial products has been observed over recent decades, as in the case of non dairy-based probiotic products (MARTINS et al., 2015b).

Fruit juices have been suggested as an appropriate medium for the addition of probiotic cultures (DOGAHE et al., 2015; PERRICONE et al., 2015) since they are healthy products widely consumed by the population and, according to Antunes et al. (2013), these products could well be the next food category to stand out on the market as probiotic bacteria carriers.

Various factors can influence the viability of probiotic bacteria in the product elaborated, including the microbial genus, species and strain, the food matrix, the formulation and composition of the product (acidity, carbohydrate content, molecular oxygen, nitrogen source, mineral content and water activity) to which they were added, the physical storage conditions (time and temperature) and possible interactions of the probiotics (bacteriocin production, antagonism and synergism) (SANTO et al., 2011). According to Champagne and Gardner (2008), the addition of probiotics to fruit juices is more complex than their addition to dairy products due to the low $\mathrm{pH}$ value of juices and insufficient 
amounts of some peptides and free amino acids required by the probiotics. It is believed this is related to the buffering potential of juices, which is inferior to that of milk, which could make it difficult to maintain the cells in the matrix.

Jabuticaba is a tropical fruit with elevated contents of carbohydrate, fiber, vitamins and mineral salts such as iron, calcium, phosphorus and potassium (TEIXEIRA, 2011). Its pulp and skin contain phenolic compounds, flavonoids and anthocyanins, which are responsible for their functional activity (SILVA et al., 2008).

The development of new flavors of probiotic juices is a promising area, principally when considering the manufacture of the juice of a fruit with commercial potential, such as jabuticaba, which could have an important role in the food industry and in that of nutritional supplements. Thus, the objective of this work was to evaluate the blanching effect on the viability of Lactobacillus rhamnosus GG before and after in vitro simulation of the digestive system and the physical-chemistry characteristics and bioactive compounds in jabuticaba juice.

\section{Material and Methods}

Obtaining the jabuticaba fruits and preparation of the pulp and juices

Jabuticaba fruits of the variety Sabara were harvested in the municipality of Rio Pomba, MG, Brazil. The fruits were sorted, washed, sanitized in a $100 \mathrm{mg} \mathrm{L}^{-1}$ active chlorine solution, rinsed in a $10 \mathrm{mg}$ $\mathrm{L}^{-1}$ chlorine solution in order to remove the chlorine residue and stored frozen at $-20{ }^{\circ} \mathrm{C}$ until used.

To obtain the pulp, one part of the fruits was triturated in a domestic blender and the mixture filtered through a nylon screen to obtain pulp A. The other part was blanched at $96{ }^{\circ} \mathrm{C}$ for 5 minutes, followed by trituration and filtering as for the nonblanched pulp, thus obtaining pulp B.

There is no specific Technical Regulation for tropical jabuticaba juice. Thus the percentage of fruit pulp was used according to Normative Instruction n. ${ }^{\circ} 12$ (BRASIL, 2003). Hence juice A was prepared with $35 \%$ pulp A, $10 \%$ sugar and $55 \%$ water, and juice $\mathrm{B}$ with $35 \%$ pulp B, $10 \%$ sugar, $0.05 \%$ carboxymethylcellulose (CMC) to reduce the astringency promoted by blanching (TEIXEIRA, 2011) and $54.95 \%$ water.

After elaboration, the $\mathrm{pH}$ value of the juices was adjusted to 5.0 using $1 \%$ potassium citrate to allow for the growth of L.rhamnosus GG (CHAMPAGNE et al., 2009; ANKOLEKAR et al., 2012). The products were packaged and pasteurized in a water

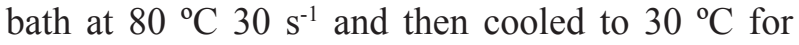
inoculation with the probiotic culture.

The control formulations consisted of juices A and B not added L. rhamnosus GG. The experiments were carried out with three repetitions.

\section{Inoculation of L.rhamnosus GG into the jabuticaba} juices

To activate the probiotic culture, two capsules containing L. rhamnosus GG (Culturelle ${ }^{\circledR}$ ) were added to $100 \mathrm{~mL}$ of pasteurized juice under aseptic conditions in a laminar flow chamber and then incubated at $36{ }^{\circ} \mathrm{C}$ for $24 \mathrm{~h}$. After incubation, an aliquot of inoculum was added to each juice in the proportion of 1:9 $\left(\mathrm{v} \mathrm{v}^{-1}\right)$ to obtain at least 6,5 $\log \mathrm{CFU} \mathrm{mL} \mathrm{m}^{-1}$ and the products were stored under refrigeration at $8{ }^{\circ} \mathrm{C}$ for 28 days.

Determination of the viability of L.rhamnosus $G G$ in the jabuticaba juices during the shelf life

The viability of the L.rhamnosus GG was determined in triplicate by deep plating in MRS agar with added bromocresol purple and calcium carbonate, the Petri dishes being incubated in anaerobic jars at $36{ }^{\circ} \mathrm{C}$ for $72 \mathrm{~h}$ (RICHER; VEDAMUTHU, 2001). The determination was carried out after inoculation (time $0 \mathrm{~d}-$ six hour after products preparation) and after 7, 14, 21 and 28 days $(7 \mathrm{~d}, 14 \mathrm{~d}, 21 \mathrm{~d}$ and $28 \mathrm{~d})$ of storage at $8{ }^{\circ} \mathrm{C}$. 
Evaluation of the survival of L. rhamnosus $G G$ under the simulated in vitro gastrointestinal conditions

The survival of $L$. rhamnosus GG was evaluated using an in vitro model by simulating the gastric and enteric juices and enzymes of the gastrointestinal tract according to the methodology proposed by Bedani et al. (2013), at time 0 (after inoculation, 0 d) and after 14 and 28 days of storage (14 d and 28 d) at $8{ }^{\circ} \mathrm{C}$.

Evaluation of coliforms and Salmonella sp. in the jabuticaba juices

Petrifilm $^{\mathrm{TM}}$ plates (3M $\mathrm{M}^{\mathrm{TM}}$ EC 6404 plates) were used to determine the total coliforms with differentiation of $E$. coli, according to the manufacturer's instructions. The presence or absence of Salmonella sp. in $25 \mathrm{~mL}$ was determined according to the methodology of Andrews et al. (2001).

All the analyses were carried out on the control treatment and on the juices containing L. rhamnosus $\mathrm{GG}$, with three repetitions each, after elaboration $(0$ d) and after 28 days of storage $(28 \mathrm{~d})$ at $8{ }^{\circ} \mathrm{C}$.

Evaluation of the physicochemical characteristics of the jabuticaba juices

Analyses of $\mathrm{pH}$, acidity and total soluble solids contents (TSS)

The physicochemical analyses for the $\mathrm{pH}$ value, total titratable acidity ( $\%$ citric acid) and total soluble solids (as ${ }^{\circ}$ Brix) were applied to the jabuticaba juices A and B containing L. rhamnosus $\mathrm{GG}$ and to the control treatments, after elaboration (time $0 \mathrm{~d}$ ) and then once a week ( $7 \mathrm{~d}, 14 \mathrm{~d}, 21 \mathrm{~d}$ and $28 \mathrm{~d}$ ) according to AOAC (2010) with three repetitions.

\section{Color analysis}

The colors of the jabuticaba juices A and B of both the control and L. rhamnosus GG containing treatments were evaluated in triplicate using a
Konica Minolta (CR10) colorimeter. The reflectance of the coordinates $\mathrm{L}^{*}, \mathrm{a}^{*}$ and $\mathrm{b}^{*}$ was read directly on the $\mathrm{L}^{*}, \mathrm{a}^{*}$ and $\mathrm{b}^{*}$ CIELAB scale, since this was adopted as the standard by the International Commission on Illumination. Three readings were taken for each sample, at different points on the sample so as to obtain a mean value.

The analyses were carried out after elaboration of the juices $(0 \mathrm{~d})$ and there after once a week $(7 \mathrm{~d}, 14$ d, $21 \mathrm{~d}$ and $28 \mathrm{~d}$ ) for the 4 weeks of storage at $8{ }^{\circ} \mathrm{C}$.

Evaluation of the antioxidant capacity, total phenolic compounds, total anthocyanins and ascorbic acid in the jabuticaba juices

The antioxidant capacity, total phenolic compounds, total anthocyanins and ascorbic acid contents of the jabuticaba juices A and B of both the control and L. rhamnosus GG containing treatments were determined at the times 0,14 and 28 days of the shelf life, with three repetitions.

\section{Antioxidant capacity}

The TEAC (Trolox equivalent antioxidant capacity) assay was applied to the jabuticaba juices using the cationic $\mathrm{ABTS}^{+}$radical, according to the methodology of Re et al. (1999) and detailed by Rufino et al. (2007), with modifications.

The cation ABTS $^{+}$(2,2'-azine-bis-(3ethylbenzothiazoline-6-sulfonic acid)) was formed by reacting $7 \mathrm{mM}$ ABTS with $2.45 \mathrm{mM}$ potassium persulfate $(1: 1)$, stored in a dark flask at room temperature for 18-24 hours. The $\mathrm{ABTS}^{+}$solution was then diluted in $80 \%$ ethanol:water $\left(\mathrm{v} \mathrm{v}^{-1}\right)$ to obtain an absorbance of 0.70 at $734 \mathrm{~nm}$. The spectrophotometer (BEL ${ }^{\circledR}$ PHOTONICS, SP 2000UV) was calibrated using $80 \%$ ethanol:water $\left(\mathrm{V} \mathrm{V}^{-1}\right)$.

Three sequential dilutions of the samples were first prepared. In a dark environment, $0.5 \mathrm{~mL}$ of each diluted sample was then transferred to test tubes and $3.5 \mathrm{~mL}$ of the radical solution $\left(\mathrm{ABTS}^{+}\right)$ added to each. The mixtures were homogenized and 
maintained in the absence of light for 6 minutes, before reading the absorbance at $734 \mathrm{~nm}$ (RE et al., 1999). A standard analytical curve was drawn with the readings obtained, with the standard antioxidant trolox varying from $10-1,100 \mu \mathrm{M}$.

In the TEAC assay, an absorbance equivalent to $10 \mu \mathrm{mol} \mathrm{L}^{-1}$ (ABTS ${ }_{10 \mu \mathrm{mol} \mathrm{L}}{ }^{-1}$ ) was obtained from the standard trolox curve equation. The value for ABTS $10 \mu \mathrm{mol} \mathrm{L}^{-1}$ was substituted in the equation of the sample curve in order to obtain the mass of

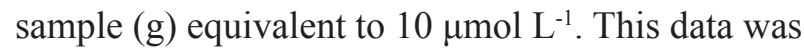

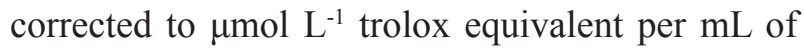
sample (TEAC).

\section{Total phenolic compounds}

In order to determine the amount of polyphenolic compounds, the samples were first eluted through a C18 separation cartridge (Waters Sep-Pak 35cc Vac) aiming to remove substances that interfere with the analysis, such as ascorbic acid, sugars and amino acids (NORATTO et al., 2010).

The total phenolic compounds, free of interfering substances, of the jabuticaba juices were determined using the Folin Ciocalteau reagent, reading the absorbance at $760 \mathrm{~nm}\left(\mathrm{BEL}^{\circledR}\right.$ PHOTONICS, SP 2000UV spectrophotometer). The calibration curves were prepared with gallic acid and the results expressed in milligrams of gallic acid equivalents per milliliter of sample (mg GAE g-1) (SINGLETON; ROSSI, 1965).

\section{Determination of total anthocyanins}

The anthocyanins in the jabuticaba juices were determined according to the methodology of Lee and Francis (1972). An aliquot of each sample was diluted in ethanol: $1.5 \mathrm{~N} \mathrm{HCl}(85: 15) \mathrm{v} \mathrm{v}^{-1}$ and the absorbance read at $535 \mathrm{~nm}$ in a spectrophotometer (BEL ${ }^{\circledR}$ PHOTONICS, SP 2000UV). The dilution was adopted so that the absorbance was between 0.200-0.800, respecting the Lambert-Beer Law. The spectrophotometer was calibrated with an ethanol: $1.5 \mathrm{~N} \mathrm{HCl}$ solution $(85: 15)$.
The anthocyanin content was obtained from Equation 1 and the final result expressed in $\mathrm{mg}$ anthocyanins per $100 \mathrm{~mL}$ of sample.

$$
\mathrm{A}=\varepsilon 1 \mathrm{~cm} \cdot \mathrm{b} \cdot \mathrm{C}^{\prime}
$$

Where:

$A=$ Absorbance (Abs) at $535 \mathrm{~nm}$

$\varepsilon_{1 \mathrm{~cm}=}$ Absorptivity coefficient $\left(98.2 \mathrm{~L} \mathrm{~cm}^{-1} \mathrm{mg}^{-1}\right)$

$\mathrm{b}=$ Width of the cuvette $(1 \mathrm{~cm})$ (light path)

$\mathrm{C}^{\prime}=$ Concentration $\left(\mathrm{g} \mathrm{L}^{-1}\right)$

\section{Determination of ascorbic acid}

Ascorbic acid was determined in the jabuticaba juices using Tillman's method according to Zenebon and Pascuet (2004) for the times of $0 \mathrm{~d}, 14 \mathrm{~d}$ and 28 d of storage at $8{ }^{\circ} \mathrm{C}$. The result was expressed in milligrams of ascorbic acid per $100 \mathrm{~mL}$ of jabuticaba juice according to equation 2 .

$$
\mathrm{AA}=((\mathrm{V}-\mathrm{v}) \times \mathrm{F} \times 100) / \mathrm{A}
$$

Where:

V: volume of Tillman's solution used to titrate the sample

v: volume of Tillman's solution used to titrate the blank

F: Tillman's solution factor

A: mL of sample

AA: $\mathrm{mg}$ ascorbic acid $100 \mathrm{~mL}^{-1}$ of juice

\section{Sensory analysis of the jabuticaba juices}

The test for acceptance of the different treatments of jabuticaba juices A and B (control and with an added probiotic culture of L. rhamnosus GG) was carried out by 50 non-trained tasters using a ninepoint hedonic scale for the attributes of color, flavor, acidity and global impression according to Minim 
(2013), after inoculation with the probiotic culture (time $0 \mathrm{~d}$ ) and after 28 days of storage at $8{ }^{\circ} \mathrm{C}(28 \mathrm{~d})$.

The project was approved by the Committee of Ethics in Research of the Federal Institute of Education of the Southeast of Minas Gerais, with the emission of a Presentation Certificate of Ethical Appreciation (CAAE nº. 36430314.4.0000.5588).

\section{Statistical analysis}

The viability of $L$. rhamnosus GG was evaluated using a completely randomized design (CRD) with three repetitions and $2 \times 5$ factorial scheme.

For the analyses of $\mathrm{pH}$, acidity, total soluble solids (TSS) and color, the CRD was designed with 3 repetitions and a $2 \times 2 \times 5$ factorial scheme, whereas for the determinations of antioxidant capacity, and the contents of total phenolic compounds, anthocyanins and vitamin $\mathrm{C}$, it was also designed using $\mathrm{CRD}$ with 3 repetitions and a $2 \times 2 \times 3$ factorial scheme.

A random block design (RBD) with a $2 \times 2 \times 2$ factorial scheme was used in the acceptance test for the attributes of color, flavor and global impression. The Principal Components Analysis (PCA) and Internal Preference Mapping were also applied using the program Past 3.09 (HAMMER et al., 2001), and the results expressed on a dispersion graph of the samples (treatments) and of each consumer in relation to the two principal components.

The analysis of variance (ANOVA) was applied to all the experiments and the means of the different treatments compared by Tukey's test considering a $5 \%$ level of probability. When there was a significant effect for time, it was studied by linear regression by way of the analysis of variance, the model being chosen according to the value for $\mathrm{P}$ obtained in the $\mathrm{F}$ test and the coefficient of determination of the corresponding model. All the analyses were carried out using the Free R Statistical Software (R DEVELOPMENT CORE TEAM, 2008) with the aid of the ExpDes packet (FERREIRA et al., 2011).

\section{Results and Discussion}

Viability of L. rhamnosus $G G$ in the jabuticaba juices and survival under simulated in vitro gastrointestinal conditions

It was shown that blanching interfered significantly with the viability of $L$. rhamnosus GG, since juice A, prepared with non-blanched fruits, showed greater viability $(\mathrm{p}<0.05)$ of this bacterium than juice $\mathrm{B}$, which was prepared with blanched fruits (Figure 1).

Figure 1. Mean counts of L. rhamnosus GG in juice A elaborated with non-blanched fruits and in juice B elaborated with blanched fruits.

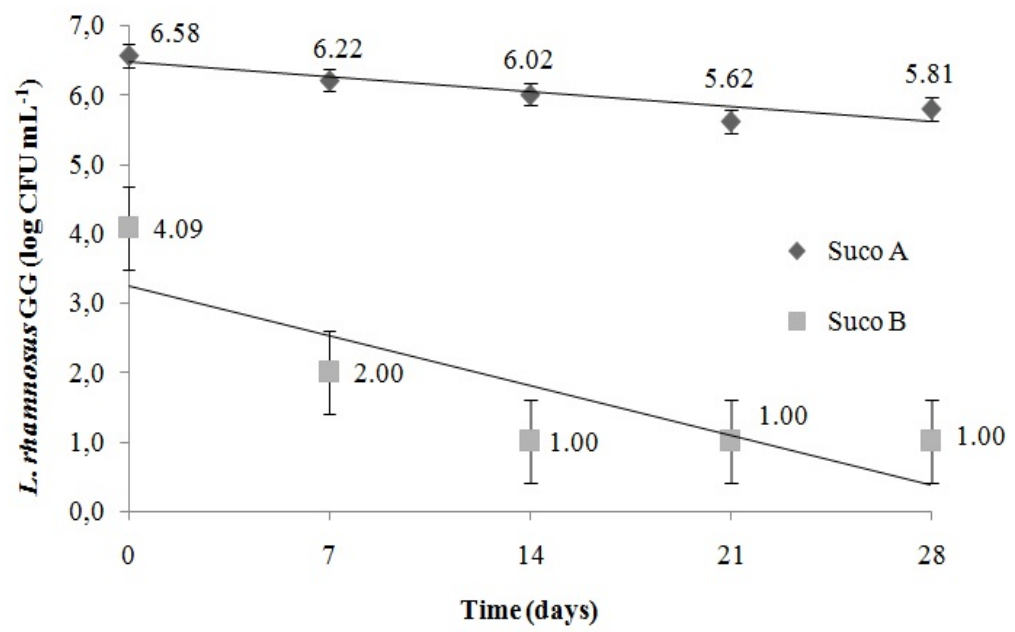


The lower count for L. rhamnosus GG in juice $B$ could be associated with the liberation of natural compounds during the fruit blanching step, that inhibit microbial growth, such as the phenolic compounds (PERRICONE et al., 2015). On studying the survival of L. plantarum in orange, grape, black rosella, pineapple, pomegranate, cranberry and lemon juices, Nualkaekul and Charalampopoulos (2011) showed a considerable loss of this bacterium viability in the pomegranate and cranberry juices, probably due to the high phenolic compound contents of these fruits.

Jabuticaba is a tropical fruit with elevated sugar and fiber contents, some mineral salts such as calcium and phosphorus, and phenolic compounds. Thus it appears that the time $\mathrm{x}$ temperature binomial used to blanch the fruits may have caused the liberation of phenolic compounds which inhibit the growth of L. rhamnosus GG once these compounds present antimicrobial effect (PERRICONE et al., 2015). According to Teixeira (2011) and Gurak et al. (2014), the use of heat has a positive effect on the extraction of these compounds from the jabuticaba skins, corroborating with the results obtained in the present study.

Time also influenced the viability of the probiotic culture in juices (Figure 1). There was a reduction in the viability during the storage period. For a product to be considered probiotic, it must have levels above $10^{6} \mathrm{CFU} \mathrm{mL}^{-1}$ (MADUREIRA et al., 2011; RATHORE et al., 2012; BANSAL et al., 2016). Based on this information, the consumption of a $100 \mathrm{~mL}$ portion of juice $\mathrm{A}$ offers the consumer above the recommended amount.

Various factors can influence the viability of probiotic bacteria in the products elaborated, amongst which the composition of the food matrix stands out, amongst other factors (SANTO et al., 2011). Perricone et al. (2015) reported that the low viability of probiotic cultures in fruit juices could be overcome by adaptation and induction of resistance by exposing the probiotics to sub-lethal stress which could induce resistance and a response to the adaptive stress, storage under refrigeration, use of antioxidants and the use of microencapsulation.

The benefit of probiotics is based mainly on the concentration in which they are found in the foods, and also on their capacity to survive adverse GIT conditions, tolerating the acid, bile and enzymes (CURTO et al., 2011; PERRICONE et al., 2015; RANADHEERA et al., 2014). In vitro assays for survival in the GIT are frequently suggested to evaluate the potential of a probiotic strain (BURITI et al., 2010; GBASSI et al., 2011).

In the presentstudy it was shown that the estimated L. rhamnosus GG count was $<1.0 \log \mathrm{CFU} \mathrm{mL}^{-1}$ at the end of the in vitro simulation, demonstrating low resistance of the strain to the matrix. According to Champagne and Gardner (2008), tolerance of the acid and bile of the gastrointestinal tract is better when the cells are added to a dairy matrix as compared to a fruit juice matrix.

In addition, according to Mainville et al. (2005), the in vitro assay with $\mathrm{pH}$ values between 1.5 and 2.5 probably overestimates the true losses in viability in the gastric phase, due to the buffering capacity of certain foods which could be consumed simultaneously with the probiotics. According to Curto et al. (2011), the in vitro digestion models developed to evaluate probiotic survival in the GIT also present some limitations, amongst which the non-removal of digestion products during the incubation period stand out, since these can present an inhibitory potential on the activity of the enzymes and survival of the probiotic cultures.

The $\mathrm{pH}$ value is one of the most important factors affecting the survival of the probiotics. Lactobacilli generally survive in juices with $\mathrm{pH}$ values varying from 3.7 to 4.3 (TRIPATHI; GIRI, 2014). Although the $\mathrm{pH}$ value is a challenge for the survival of these microorganisms in juices, Ranadheera et al. (2014) affirmed that the incorporation of lactic bacteria into low $\mathrm{pH}$ value fruit juices could increase their resistance to subsequent stressful acid conditions, 
such as those of the GIT, but this was not verified in this work.

Although the viability of L. rhamnosus GG was not observed after the in vitro trial, its probiotic activity was not evaluated. Research has suggested that the administration of dead probiotic cells could provide beneficial effects to the host, principally with respect to their anti-inflammatory actions, which indicates that the viability of the probiotic cells is not obligatory in order to confer therapeutic effects (ADAMS, 2010).

\section{Evaluation of coliforms and Salmonella sp.}

RDC resolution $\mathrm{n}^{\circ} 12$ of the National Sanitary Vigilance Agency (BRASIL, 2001) defined a maximum of $10 \mathrm{CFU} \mathrm{mL}-1$ of coliforms at $45^{\circ} \mathrm{C}$ and the absence of Salmonella sp. in $25 \mathrm{~mL}$ of product, as the standard for juices, soft drinks and other non- alcoholic beverages. Thus according to Brazilian legislation, the jabuticaba juices conformed to the established microbiological requisites, with counts

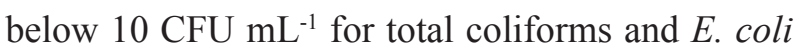
and the absence of Salmonella sp. in $25 \mathrm{~mL}$ of the samples.

Physicochemical characteristics of the jabuticaba juices

Probiotic addition did not influence $(p>0,05)$ $\mathrm{pH}$ and acidity. Besides, there was no statistical interaction between the parameters of $\mathrm{pH}$ and acidity of the juices and hence they were studied separately. It was shown that the blanching process (Table 1) and storage time (Figure 2) both significantly $(\mathrm{p}<0.05)$ influenced the $\mathrm{pH}$ values, whereas the acidity was only affected by the blanching process $(p<0.05)$ (Table 1), this parameter not changing during storage.

Figure 2. Effect of storage time on the $\mathrm{pH}$ value of the jabuticaba juices. Regression model coefficients are significant at $5 \%$ of probability according to the regression analysis.

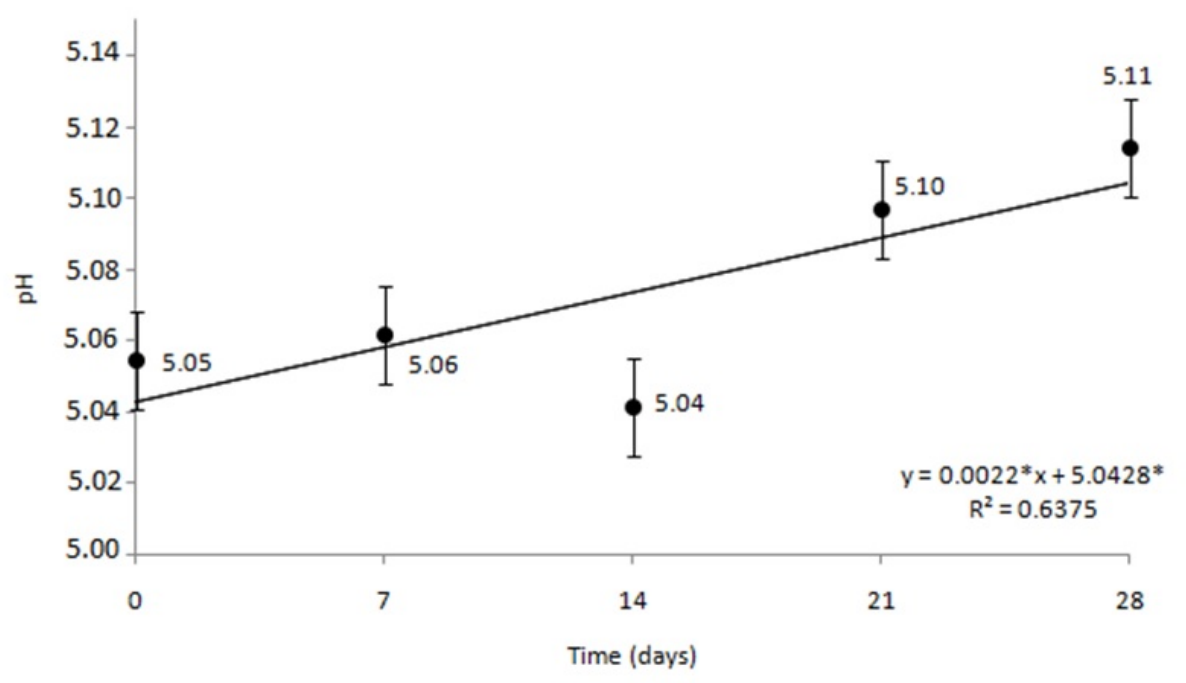


Table 1. Mean results for $\mathrm{pH}$ value, acidity and total soluble solids ( $\left.{ }^{\circ} \mathrm{Brix}\right)$ of the jabuticaba juices prepared with nonblanched (Juice A) and blanched (Juice B) fruits.

\begin{tabular}{lccc}
\hline \multirow{2}{*}{ Treatments } & \multicolumn{3}{c}{ Physicochemical characteristics } \\
\cline { 2 - 4 } & $\mathrm{pH}$ & Acidity & Total soluble solids $\left({ }^{\circ}\right.$ Brix $)$ \\
\hline Juice A & $5.03 \mathrm{a}$ & $0.46 \mathrm{a}$ & $15.38 \mathrm{a}$ \\
Juice B & $5.12 \mathrm{~b}$ & $0.66 \mathrm{~b}$ & $16.05 \mathrm{~b}$ \\
\hline
\end{tabular}

Means followed by the same letter in the same column do not differ statistically according to Tukey's test at $5 \%$ probability.

The $\mathrm{pH}$ values increased throughout storage as shown by the linear regression model (Figure 2). On analyzing a jabuticaba nectar maintained at 8 ${ }^{\circ} \mathrm{C}$ for 4 months, Garcia (2014) also observed that this parameter varied throughout the storage time, increasing from 3.59 to 3.65 in the first 30 days of storage.

Juice B showed higher values for $\mathrm{pH}$ than juice $\mathrm{A}$, but this does not infer that the difference was due to the blanching process, since after processing, the $\mathrm{pH}$ of the juice was corrected to 5.0. Juice B also presented greater acidity than juice A (Table 1). However this difference $(\mathrm{p}<0.05)$ was not perceptible at the consumer level, as shown by the sensory analysis data in which the scores attributed to the acidity of juices A and B were statistically the same ( $\mathrm{p}>0.05)$.

According to Chim et al. (2013), the acidity is an important quality characteristic of a product, in which reactions involved in product decomposition, such as hydrolysis, oxidation and fermentation, produce acid compounds which, in consequence, increase the acidity of the medium. This was not evident in the present study, in which the acidity of the jabuticaba juices remained constant during storage.

Juice B showed significantly $(p<0.05)$ higher TSS values than juice A (Table 1) and the addition of L. rhamnosus GG did not alter the physicochemical parameters evaluated $(p>0.05)$. The storage time did not interfere with TSS contents, which remained constant ( $p>0.05)$ during the 28 days of storage.

Garcia (2014) also observed that the TSS content remained constant during the 30 days of refrigerated storage of jabuticaba nectar. According to Chim et al. (2013), the soluble solids are mainly constituted of sugars which are used by the microorganisms as a source of energy for growth. These authors reported that the storage temperature exerted an influence on the action of the microorganisms and consequently on the maintenance of the TSS, and hence they noted that acerola nectar showed greater retention of TSS during frozen storage than when maintained at room temperature.

The higher TSS content of juice $B(p<0.05)$ (Table 1) can be explained by the fact that carboxymethylcellulose (CMC) was added to this juice. According to Leal et al. (2014), CMC is a polysaccharide obtained by the chemical modification of cellulose and is soluble in aqueous systems at room temperature. Caleguer and Benassi (2007) also observed an increase in soluble solids in orange-flavored drinks with added CMC. Another factor that could have contributed to the higher TSS content of juice B was the fact that the fruits were blanched, resulting in a greater extraction of phenolic compounds. According to Taiz and Zeiger (2004), the vegetable phenolic compounds constitute a chemically heterogeneous group, some only being soluble in organic solvents, whilst others are water-soluble carboxylic acids and glycosides, and others even large insoluble polymers.

\section{Color of the jabuticaba juices}

The mean value for the luminosity ( $\left.\mathrm{L}^{*}\right)$ of juice B (21.54) was significantly lower $(p<0.05)$ than the value obtained for juice A (34.84), evidence of the influence of the blanching process on luminosity. 
These results show that the juices prepared with blanched fruits were darker due to the liberation of compounds from the skins, which, according to Nunes et al. (2014), show a dark red, almost black, coloration. The addition of a probiotic culture and storage at $8^{\circ} \mathrm{C}$ for 28 days did not alter $(\mathrm{p}>0.05)$ the values for $\mathrm{L}^{*}$, showing that the juices did not get darker during storage.

The addition of the probiotic culture did not interfere with coordinate $\mathrm{a}^{*}$. There was interaction between the time and the blanching process, and the values for $\mathrm{a}^{*}$ were significantly higher for juice
B than for juice A for each point in time evaluated (Table 2), although this coordinate did not vary with time for any of the juices (juices A and B). Since coordinate $\mathrm{a}^{*}$ varies from green (-) to red $(+)$, it was shown that juice B had a greater tendency for red. On evaluating the color of frozen jabuticaba pulp, Garcia (2014) and Nunes et al. (2014) also observed a reddish color. The redder color of juice $\mathrm{B}$ again inferred that blanching liberated compounds present in the skin. It was also shown that the mean values for the coordinate $\mathrm{a}^{*}$ did not differ with time for juices A and B (Table 2).

Table 2. Mean results for coordinate $\mathrm{a}^{*}$ and coordinate $\mathrm{b}^{*}$ of the jabuticaba juices A and B at different storage times.

\begin{tabular}{ccccc}
\hline \multirow{2}{*}{$\begin{array}{c}\text { Time } \\
\text { (days) }\end{array}$} & \multicolumn{2}{c}{ Coordinate $\mathrm{a}^{*}$} & \multicolumn{2}{c}{ Coordinate $\mathrm{b}^{*}$} \\
\cline { 2 - 5 } & Juice A & Juice B & Juice A & Juice B \\
\hline 0 & $4.89 \mathrm{a}$ & $16.57 \mathrm{~b}$ & $2.55 \mathrm{a}$ & $15.07 \mathrm{~b}$ \\
7 & $5.71 \mathrm{a}$ & $15.31 \mathrm{~b}$ & $2.31 \mathrm{a}$ & $22.75 \mathrm{~b}$ \\
14 & $6.95 \mathrm{a}$ & $14.33 \mathrm{~b}$ & $3.02 \mathrm{a}$ & $20.48 \mathrm{~b}$ \\
21 & $7.76 \mathrm{a}$ & $12.92 \mathrm{~b}$ & $2.58 \mathrm{a}$ & $22.13 \mathrm{~b}$ \\
28 & $7.49 \mathrm{a}$ & $13.47 \mathrm{~b}$ & $3.66 \mathrm{a}$ & $20.61 \mathrm{~b}$ \\
\hline
\end{tabular}

Means followed by the same small letter in the same line and same column for coordinate $\mathrm{a}^{*}$ and means followed by the same small letter in the same line for coordinate $b^{*}$, do not differ from each other according to Tukey's test at 5\% probability. Juice A (non-blanched fruits) and juice B (blanched fruits).

As for coordinate $a^{*}$, coordinate $b^{*}$ also showed an interaction with the time and blanching process $(\mathrm{p}<0.05)$. The values for $\mathrm{b}^{*}$ for juices $\mathrm{A}$ and $\mathrm{B}$ were significantly $(\mathrm{p}<0.05)$ different at all points in time analyzed (Table 2). It was observed that the values for coordinate $b^{*}$ of juice B did not vary throughout storage $(p>0.05)$, to the contrary of that observed for juice $A(p<0.05)$, where the effect of time was studied by regression and showed that the value for this coordinate increased up to the $14^{\text {th }}$ day of storage.

The coordinate $b^{*}$ varies from blue (-) to yellow $(+)$. It was shown that, despite the variations, both samples presented positive values, with juice B showing a greater tendency for yellow. Similar results were obtained by Garcia (2014) and Nunes et al. (2014), on studying frozen jabuticaba pulp.
Antioxidant capacity, total phenolic compounds and total anthocyanins in the jabuticaba juices

No effect of storage time or the addition of probiotic on the antioxidant capacity, total phenolic compounds or total anthocyanins was observed. However, blanching contributed significantly $(p<0.05)$ to increase the contents of these compounds in the juices prepared with blanched fruits (Table 3).

Jabuticabas contain elevated amounts of polyphenolic compounds, such as anthocyanins, which are concentrated in the dark-colored skin (ALEZANDRO et al., 2013). The greater antioxidant capacity and greater total phenolic compound and anthocyanin contents in juice $B$ were due to the liberation of these compounds, present mainly in the skin (LIMA et al., 2008), due to the application of heat during blanching. 
Table 3. Mean contents obtained for the antioxidant capacity, total phenolic compounds and total anthocyanins of the jabuticaba juices.

\begin{tabular}{|c|c|c|c|}
\hline Treatments & $\begin{array}{c}\text { Antioxidant capacity } \\
\left(\mu \mathrm{M} \text { Trolox } \mathrm{g}^{-1}\right)\end{array}$ & $\begin{array}{l}\text { Total phenolic compounds } \\
\left.\text { (mg GAE } 100 \mathrm{~g}^{-1}-\mathrm{wwb}\right)\end{array}$ & $\begin{array}{c}\text { Anthocyanins } \\
\left.\text { (mg } 100 \mathrm{~mL}^{-1}-\mathrm{wwb}\right)\end{array}$ \\
\hline Juice A & $186.20 \mathrm{a}$ & $275.06 \mathrm{a}$ & $12.71 \mathrm{a}$ \\
\hline Juice B & $2552.59 \mathrm{~b}$ & $1163.18 \mathrm{~b}$ & $90.99 b$ \\
\hline
\end{tabular}

$\mathrm{wwb}=$ wet weight basis; GAE= gallic acid equivalent. Means followed by the same small letter in the same column do not differ from each other according to Tukey's test at 5\% probability. Juice A (non-blanched fruits) and juice B (blanched fruits).

Lima et al. (2008) reported that when the extraction is carried out at high temperatures, a greater quantity of these substances is obtained, corroborating with the results of Falcão et al. (2007), who observed that heating helped in the transference of pigments from grape skins to the must, in addition to helping inactivate the anthocyanin-degrading enzymes, thus preserving the anthocyanins. Moreira (2015), working with a mixed juçara and Ubá manga juice treated by pasteurization and high hydrostatic pressure (HHP), also showed the effect of heat in extracting the phenolic compounds, such that greater values were found for this substance and a greater antioxidant capacity in the pasteurized juices as compared to the HHP processed ones.

Cipriano (2011), on analyzing fresh jabuticaba

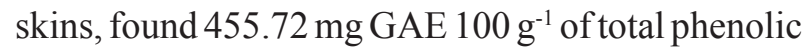
compounds, $65.28 \mathrm{mg} 100 \mathrm{~g}^{-1}$ of anthocyanins and $12.34 \mu \mathrm{M}$ Trolox $\mathrm{g}^{-1}$ for antioxidant capacity. These values are lower than those found in the present study for juice B, due to the fact that, in the latter case, the fruits had been submitted to a prior heating and trituration to elaborate the product.

Jabuticaba is a promising fruit with an antioxidant capacity similar to that of other superfruits, such as, for example, the grape (WU et al., 2013) and the fruits of the Juçara palm (MOREIRA, 2015). The phenolic compounds are potent natural antioxidants and are probably responsible for the elevated antioxidant capacity of jabuticaba.

\section{Ascorbic acid}

The ascorbic acid content of the juices analyzed in the present study did not vary as a function of storage time or the treatments evaluated $(p>0.05)$, remaining stable at $72.87 \mathrm{mg} 100 \mathrm{~mL}^{-1}$ throughout the shelf life. According to the USA Institute of Medicine (2005), the recommended daily intake (RDI) of vitamin $\mathrm{C}$ for individuals over 19 years of age is $90 \mathrm{mg} \mathrm{day}^{-1}$ for men and $75 \mathrm{mg} \mathrm{day}^{-1}$ for women. Thus the intake of $100 \mathrm{~mL}$ of jabuticaba juice represents $80.96 \%$ and $97.16 \%$ of the recommended daily needs for male and female adults, respectively, being considered rich in vitamin $\mathrm{C}$.

The ascorbic acid found in the present study was higher than that reported by Inada et al. (2015), who, on analyzing jabuticaba pulp by HPLC, found 8.6 $\mathrm{mg}$ of vitamin $\mathrm{C}$ per $100 \mathrm{~mL}$ of pulp. This low value was due to the fact that the authors only analyzed the pulp, whereas the juices analyzed in the present study were prepared with the whole fruit.

\section{Sensory characteristics of the jabuticaba juices}

The tasters found no difference in color between the juices due to the addition of $L$. rhamnosus GG $(\mathrm{p}>0.05)$. However, juice B showed a mean score of 7.95 (equivalent to 'liked moderately') for this attribute, significantly higher $(\mathrm{p}<0.05)$ than the score awarded to juice A of 6.41 (equivalent to 'liked slightly'), a fact providing evidence of the effect of the blanching process on the color of the juice (Table 4). 
Table 4. Means for the attributes of color, flavor and global impression of the jabuticaba juices of the different treatments after preparation $(0 \mathrm{~d})$ and after 28 days $(28 \mathrm{~d})$ of storage at $8{ }^{\circ} \mathrm{C}$.

\begin{tabular}{|c|c|c|c|c|c|c|c|c|c|}
\hline \multirow{2}{*}{ Samples } & \multicolumn{3}{|c|}{ Color } & \multicolumn{3}{|c|}{ Flavor } & \multicolumn{3}{|c|}{ Global impression } \\
\hline & $0 \mathrm{~d}$ & $28 \mathrm{~d}$ & Mean & $0 \mathrm{~d}$ & $28 \mathrm{~d}$ & Mean & $0 \mathrm{~d}$ & $28 \mathrm{~d}$ & Mean \\
\hline $\begin{array}{l}\text { Juice A with added } L \text {. } \\
\text { rhamnosus GG }\end{array}$ & 6.32 & 6.46 & \multirow[t]{2}{*}{$6.41 \mathrm{a}$} & 7.22 & 6.66 & \multirow[t]{2}{*}{$6.83 a$} & 6.82 & 6.84 & \multirow[t]{2}{*}{$6.98 \mathrm{a}$} \\
\hline Control juice A & 6.44 & 6.42 & & 6.58 & 6.88 & & 7.12 & 7.16 & \\
\hline $\begin{array}{l}\text { Juice B with added } L \text {. } \\
\text { rhamnosus GG }\end{array}$ & 7.88 & 7.98 & \multirow[t]{2}{*}{$7.95 b$} & 6.88 & 6.64 & \multirow[t]{2}{*}{$6.84 \mathrm{a}$} & 7.26 & 7.10 & \multirow[t]{2}{*}{$7.17 \mathrm{a}$} \\
\hline Control juice B & 7.92 & 8.04 & & 7.16 & 6.68 & & 7.26 & 7.10 & \\
\hline Mean & $7.14 \mathrm{~A}$ & $7.22 \mathrm{~A}$ & & $6.96 \mathrm{~A}$ & $6.71 \mathrm{~A}$ & & $7.11 \mathrm{~A}$ & $7.05 \mathrm{~A}$ & \\
\hline
\end{tabular}

Small letters indicate the comparison of the means in the lines and capital letters indicate the comparison of the means in the columns. Means followed by the same letter do not differ from each other according to Tukey's test ( $p<0.05$ ). Juice A (nonblanched fruits) and juice B (blanched fruits).

There was no difference between juices A and $B(p>0.05)$ for the attributes of flavor and global impression, evidence that the addition of $L$. rhamnosus GG and the blanching process did not modify these attributes according to the consumers.

An important area in the strategic development of a product is the identification of possible consumer segmentation. Thus preference mapping methodology is frequently employed to identify groups of consumers that respond in a uniform way (LOVELY; MEULLENET, 2009).

An analysis of the principal components (Figure 3) showed that, for the attribute of color, the juice samples prepared with blanched fruits of the control treatment, after 28 days of storage (juice B C $28 \mathrm{~d}$ ), and those prepared with blanched fruits containing L. rhamnosus $\mathrm{GG}$, after 28 days of storage (juice B P $28 \mathrm{~d}$ ), both located in quadrant I; and those prepared with blanched fruits containing L. rhamnosus GG, immediately after processing (juice B P $0 \mathrm{~d}$ ), and those prepared with blanched fruits of the control treatment, immediately after processing (juice B C 0 d), both located in quadrant IV, are close to each other, and hence show similar acceptance. In addition, the positions of the vectors show there was greater acceptance of the color of juices B as compared to juices $\mathrm{A}$, the latter being found in the opposite quadrants (Figure 3).

With respect to the attribute of acidity, an influence of the addition of the probiotic culture can be seen since the tasters considered juices $\mathrm{A}$ and $\mathrm{B}$ containing $L$. rhamnosus $\mathrm{GG}$ to be more acid (score of 7.1) than juices $A$ and $B$ of the control treatment (score of 6.8) $(\mathrm{p}<0.05)$. The mean values for acidity of the probiotic juices were higher than for those of the control treatment due to the addition of the fermented inoculum. Nevertheless it was shown by way of the physicochemical analyses that the means were statistically the same, showing that the consumers detected other product constituents that interfered with the acid flavor. The different food acids show very distinct gustatory profiles.

Also related to acidity, there was an interaction between the blanching process and storage time, only juice B showing changes in the score for this attribute with time $(\mathrm{p}<0.05)$. This result was complemented by the preference map (Figure 4), in which it can be seen that juices B (with and without L. rhamnosus GG) immediately after processing (0 d), located in quadrant $\mathrm{I}$, were situated on opposite sides from juices B with 28 days of storage, located in quadrants II and III. 
Figure 3. Internal preference map for the color of the jabuticaba juices of the treatments.

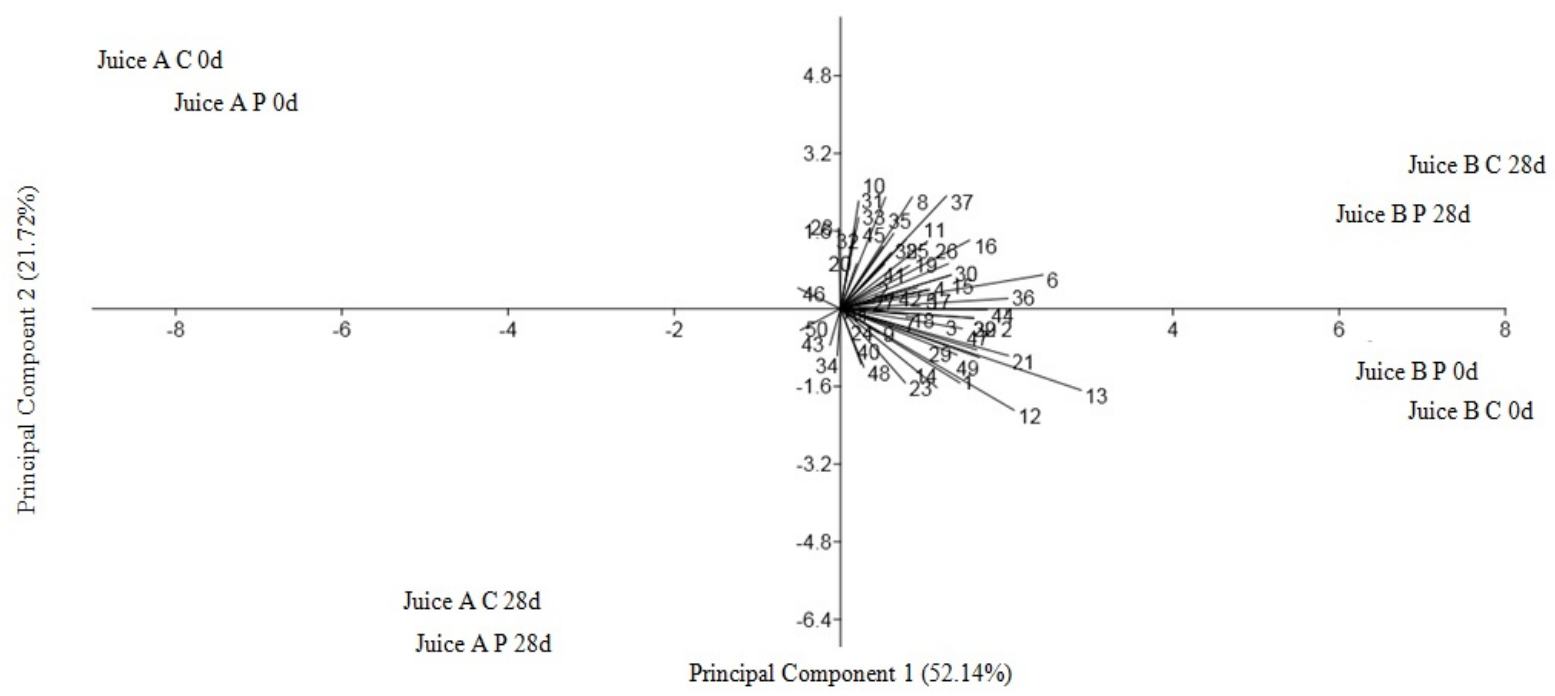

Juice A C 0 d: juice prepared with non-blanched fruits of the control treatment,immediately after processing; juice A C 28 d:juice prepared with non-blanched fruits of the control treatment,after 28 daysof storage; juice A P 0 d: juice prepared with non-blanched fruits containing L. rhamnus GG, immediately after processing; juice A P 28 d: juice prepared with non-blanched fruits containing L. rhamnus GG, after 28 days of storage; juice B C 0 d: juice prepared with blanched fruits of the control treatment,immediately after processing; juice B C 28 d: juice prepared with blanched fruits of the control treatment,after 28 days of storage; juice B P 0 d: juice prepared with blanched fruits containing L. rhamnus GG, immediately after processing; juice B P 28 d: juice prepared with blanched fruits containing L. rhamnus GG, after 28 days of storage.

Figure 4. Internal preference map for the attribute of acidity of the jabuticaba juices A and B of the different treatments.

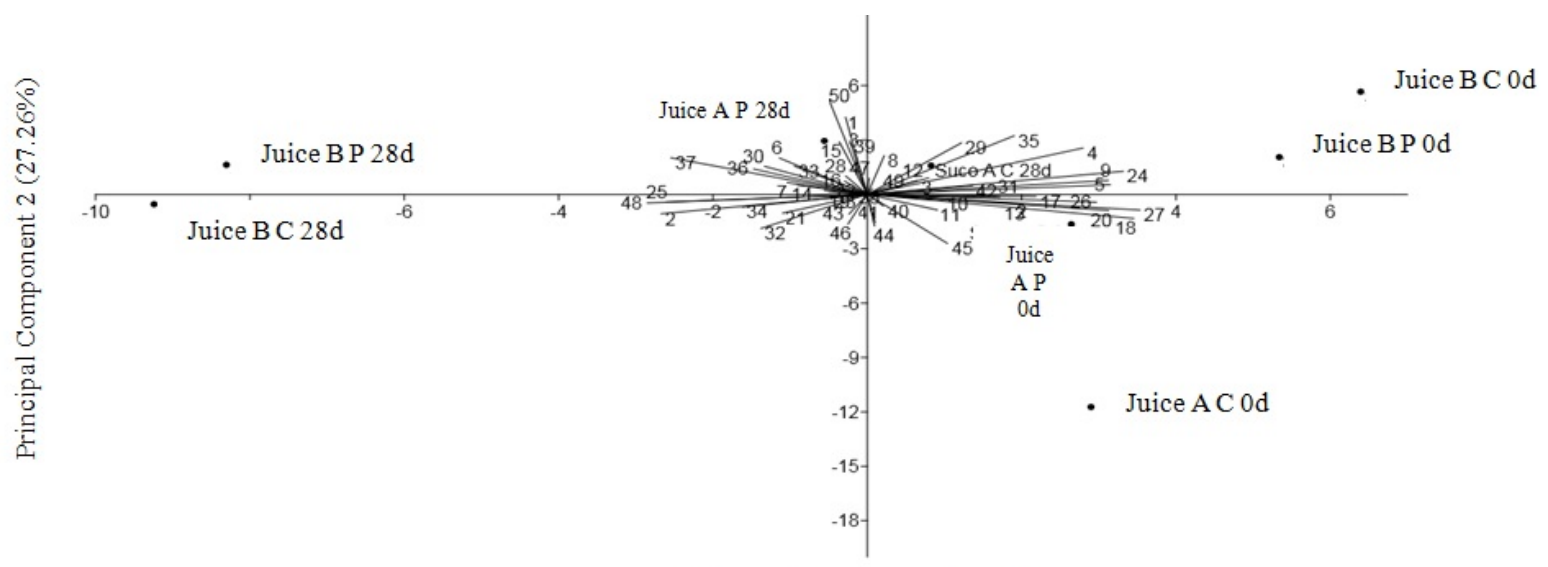

Principal Component $1(34.3 \%)$

Juice A C 0 d: juice prepared with non-blanched fruits of the control treatment,immediately after processing; juice A C $28 \mathrm{~d}$ : juice prepared with non-blanched fruits of the control treatment,after 28 days of storage; juice A P 0 d: juice prepared with non-blanched fruits containing L. rhamnus GG, immediately after processing; juice A P 28 d: juice prepared with non-blanched fruits containing L. rhamnus GG, after 28 days of storage; juice B C 0 d: juice prepared with blanched fruits of the control treatment,immediately after processing; juice B C 28 d: juice prepared with blanched fruits of the control treatment,after 28 days of storage; juice B P 0 d: juice prepared with blanched fruits containing $L$. rhamnus $\mathrm{GG}$, immediately after processing; juice B P 28 d: juice prepared with blanched fruits containing L. rhamnus $\mathrm{GG}$, after 28 days of storage. 


\section{Conclusions}

Blanching affected the viability of L. rhamnosus GG in the jabuticaba juice, and the juices elaborated in this work were not good vehicles for L. rhamnosus GG. The probiotic culture did not survive the in vitro GIT assay in any of the juices and hence the use of co-cultures and prebiotics is suggested, associated with microencapsulation so as to promote the growth and maintenance of the culture in the product.

Coliforms and salmonela were not detected in any of the juice samples, indicating that the products conformed to the microbiological standard established by the Brazilian legislation, and were safe for human consumption.

The ascorbic acid content of the juices was maintained throughout the shelf life. The jabuticaba juices contained considerable amounts of polyphenolic compounds, which were probably responsible for the considerable antioxidant activities of the products, showing the importance of using the whole jabuticaba fruit to elaborate the juice. The application of heat was relevant in the extraction of the phenolic compounds, greater antioxidant capacity and greater anthocyanin contents being detected in the juices prepared with blanched fruits.

The formulations were shown to be promising, with scores above 6.0 on the nine-point hedonic scale in the sensory analysis, in addition to showing a functional appeal, of importance when one considers the new consumer demands searching for foods that are healthy as well as flavorful and visually attractive.

\section{Acknowledgements}

The authors are grateful to the Brazilian Science and Technology Research Council (CNPq, Brazil) and to the Research Foundation of the State of Minas Gerais (FAPEMIG, Brazil) and to the Federal Institute of the Southeast of Minas Gerais, for their financial support.

\section{References}

ADAMS, C. A. The probiotic paradox: live and dead cells are biological response modifiers. Nutrition Research Reviews, Cambridge, v. 23, n. 1, p. 37- 46, 2010.

ALEZANDRO, M. R.; GRANATO, D.; GENOVESE, M. I. Jaboticaba (Myrciaria jaboticaba (Vell.) Berg), a Brazilian grape-like fruit, improves plasma lipid profile in streptozotocin-mediated oxidative stress in diabetic rats. Food Research International, Amsterdam, v. 54, n. 1, p. 650-659, 2013.

ANDREWS, W. H.; FLOWER, R. S.; SILLIKER, J.; BAILEY, J. S. Salmonella. In: DOWNES, F. P.; ITO, K. (Ed.). Compendium of methods for the microbilological examination of foods. $4^{\text {th }}$ ed. Washington: American Public Health Association - APHA, 2001. p. 357-380.

ANKOLEKAR, C.; PINTO, M.; GREENE, D.; SHETTY, K. In vitro bioassay based screening of antihyperglycemia and antihypertensive activities of Lactobacillus acidophilus fermented pear juice. Innovative Food Science and Emerging Technologies, Oxford, v. 13, p. 221-230, 2012.

ANTUNES, A. E. C.; LISERRE, A. M.; COELHO, A. L. A.; MENEZES, C. R., MORENO, I.; YOTSUYANAGI, K.; AZAMBUJA, N. C. Acerola nectar with added microencapsulated probiotic. $L W T-$ Food Science and Technology, Amsterdam, v. 54, n. 1, p. 125-131, 2013.

ASSOCIATION OF OFFICIAL ANALITICAL CHEMISTS - AOAC. Official methods of analysis of the AOAC. 18. ed. Washington: Association of Analytical Communities, 2010.

BANSAL, S.; MANGAL, M.; SHARMA, S. K.; YADAV, D. N.; GUPTA, R. K. Optimization of process conditions for developing yoghurt like probiotic product from peanut. LWT - Food Science and Technology, Amsterdam, v. 73, p. 6-12, 2016.

BEDANI, R.; ROSSI, E. A.; SAAD, S. M. Impact of inulin and okara on Lactobacillus acidophilus La-5 and Bifidobacterium animalis $\mathrm{Bb}-12$ viability in a fermented soy product and probiotic survival under in vitro simulated gastrointestinal conditions. Food Microbiology, London, v. 34, n. 2, p. 382-389, 2013.

BRASIL. Ministério da Agricultura, Pecuária e Abastecimento. Instrução Normativa $n .^{\circ} 12$, de 4 de setembro de 2003. Aprova o Regulamento Técnico para Fixação dos Padrões de Identidade e Qualidade Gerais para Suco Tropical e os Padrões de Identidade e Qualidade dos Néctares. Diário Oficial [da] União, Brasília, 9 set. 2003. Seção 1, p. 2.

Ministério da Saúde. Agência Nacional de Vigilância Sanitária. Resolução RDC n. ${ }^{\circ} 12$, de 2 de 
janeiro de 2001. Aprova o Regulamento Técnico sobre Padrões Microbiológicos para Alimentos. Diário Oficial [da] União, Brasília, 10 jan. 2001. Seção 1, p. 45-53.

BURITI, F. C. A.; CASTRO, I. A.; SAAD, S. M. I. Viability of Lactobacillus acidophilus in synbiotic guava mousses and its survival under in vitro simulated gastrointestinal conditions. International Journal of Food Microbiology, London, v. 137, n. 2-3, p. 121-129, 2010.

CALEGUER, V. F.; BENASSI, M. T. Efeito da adição de polpa, carboximetilcelulose e goma arábica nas características sensoriais e aceitação de preparados em pó para refresco sabor laranja. Ciência e Tecnologia de Alimentos, Campinas, v. 27, n. 2, p. 270-277, 2007.

CHAMPAGNE, C. P.; GARDNER, N. J. Effect of storage in a fruit drink on subsequent survival of probiotic lactobacilli to gastro-intestinal stresses. Food Research International, Amsterdam, v. 41, n. 5, p. 539-543, 2008.

CHAMPAGNE, C. P.; GREEN-JOHNSON, J.; RAYMOND, Y.; BARRETTE, J.; BUCKLEY, N. Selection of probiotic bacteria for the fermentation of a soy beverage in combination with Streptococcus thermophilus. Food Research International, Amsterdam, v. 42, n. 5-6, p. 612-621, 2009.

CHIM, J. F.; ZAMBIAZI, R. C.; RODRIGUES, R. $\mathrm{S}$. Estabilidade da vitamina $\mathrm{C}$ em néctar de acerola sob diferentes condições de armazenamento. Revista Brasileira de Produtos Agroindustriais, Campina Grande, v. 15, n. 4, p. 321-327, 2013.

CIPRIANO, P. A. Antocianinas de açaí (Euterpe oleracea Mart.) e casca de jabuticaba (Myrciaria jaboticaba) na formulação de bebidas isotônicas. 2011. Dissertação (Mestrado em Ciência e Tecnologia de Alimentos) Universidade Federal de Viçosa, Viçosa, MG.

CURTO, A. L.; PITINO, I.; MANDALARI, G.; DAINTY, J. R.; FAULKS, R. M.; WICKHAM, M. S. J. Survival of probiotic lactobacilli in the upper gastrointestinal tract using an in vitro gastric model of digestion. Food Microbiology, London, v. 28, n. 7, p. 1359-1366, 2011.

DOGAHE, M. K.; KHOSRAVI-DARANI, K.; TOFIGHI, A.; DADGAR, M.; MORTAZAVIAN, A. M. Effect of process variables on survival of bacteria in probiotics enriched pomegranate juice. British Biotechnology Journal, London, v. 5, n. 1, p. 37-50, 2015.

FALCÃO, A. P.; CHAVES, E. S.; KUSKOSKI, E. M.; FETT, R.; FALCÃO, L. D.; BORDIGNON-LUIZ, M. T. Índice de polifenóis, antocianinas totais e atividade antioxidante de um sistema modelo de geleia de uvas. Ciência e Tecnologia de Alimentos, Campinas, v. 27, n. 3, p. 637-642, 2007.
FERREIRA, E. B.; CAVALCANTI, P. P.; NOGUEIRA, D. A. Experimental designs: um pacote R para análise de experimentos. Revista de Estatística da UFOP, Ouro Preto, v. 1, n. 1, p. 1-9, 2011.

GARCIA, L. G. C. Aplicabilidade tecnológica da jabuticaba. 2014. Dissertação (Mestrado em Ciência e Tecnologia de Alimentos) - Universidade Federal de Goiás, Goiânia.

GBASSI, G. K.; VANDAMME, T.; YOLOU, F. S.; MARCHIONI, E. In vitro effects of $\mathrm{pH}$, bile salts and enzymes on the release and viability of encapsulated Lactobacillus plantarum strains in a gastrointestinal model. International Dairy Journal, Oxford, v. 21, n. 2, p. 97-102, 2011.

GURAK, P. D.; DE BONA, G. S.; TESSARO, I. C.; MARCZAK, L. D. F. Jaboticaba pomace powder obtained as a co-product of Juice extraction: a comparative study of powder obtained from peel and whole fruit. Food Research International, Amsterdam, v. 62, p. 786-792, 2014.

HAMMER, Ø.; HARPER, D. A. T.; RYAN, P. D. PAST: Paleontological statistics software package for education and data analysis. Paleontologia Electronica, California, v. 4 , n. 1, p. 1-9, 2001. Available at: $<$ http://palaeoelectronica.org/2001_1/past/issue1_01.htm>. Accessed at: 23 fev. 2016.

INADA, K. O. P.; OLIVEIRA, A. A.; REVORÊDO, T. B.; MARTINS, A. B. N.; LACERDA, E. C. Q.; FREIRE, A. S.; BRAZ, B. F.; SANTELLI, R. E.; TORRES, A. G.; PERRONE, D.; MONTEIRO, M. Screening of the chemical composition and occurring antioxidants in jabuticaba (Myrciaria jaboticaba) and jussara (Euterpe edulis) fruits and their fractions. Journal of Functional Foods, St. John's, v. 17, p. 422-433, 2015.

INSTITUTE OF MEDICINE. Dietary reference intakes for vitamin C, vitamin E, selenium, and carotenoids. Washington: National Academy Press, 2005.

KUMAR, B. V.; VIJAYENDRA, S. V. N.; REDDY, O. V. S. Trends in dairy and non-dairy probiotic products - a review. Journal of Food Science and Technolology, Cham, v. 52, n. 10, p. 6112-6124, 2015.

LEAL, A. S.; LOPES, J. A. D.; SILVA, D.; FREITAS, R. M.; ARAÚJO, I. M. S. Desenvolvimento de filmes de carboximetilcelulose para encapsulamento de drogas: uma prospecção tecnológica. Revista GEINTEC, São Cristóvão, v. 4, n. 1, p. 467-479, 2014.

LEE, D. H.; FRANCIS, F. J. Standardization of pigment analyses in cranberries. Hort Science, Stanford, v. 7, n. 1, p. 83-84, 1972. 
LIMA, A. J. B.; CORRÊA, A. D.; ALVES, A. P. C.; ABREU, C. M. P.; DANTAS-BARROS, A. M. Caracterização química do fruto jabuticaba (Myrciaria cauliflora) e de suas frações. Archivos Latinoamericanos de Nutrición, Caracas, v. 58, n. 4, p. 416-421, 2008.

LOVELY, C.; MEULlENET, J. F. Comparison of preference mapping techniques for the optimization of strawberry yogurt. Journal of Sensory Studies, Dublin, v. 24, n. 4, p. 457-478, 2009.

MADUREIRA, A. R.; AMORIM, M.; GOMES, A. M.; PINTADO, M. E.; MALCATA, F. X. Protective effect of whey cheese matrix on probiotic strains exposed to simulated gastrointestinal conditions. Food Research International, Amsterdam, v. 44, n. 1, p. 465-470, 2011.

MAINVILLE, I.; ARCAND, Y.; FARNWORTH, E. R. A dynamic model that simulates the upper gastrointestinal tract for the study of probiotics. International Journal of Food Microbiology, London, v. 99, n. 3, p. 287-296, 2005.

MARTINS, E. M. F.; RAMOS, A. M.; MARTINS, M. L.; OLIVEIRA, P. M.; STRINGHETA, P. C. Minimally processed fruit salad enriched with Lactobacillus acidophilus: viability of anti-browning compounds in the preservation of color. African Journal of Biotechnology, Nairobi, v. 14, n. 24, p. 2022-2027, 2015 b.

MARTINS, E. M. F.; RAMOS, A. M.; MARTINS, M. L.; RODRIGUES, M. Z. Research and development of probiotic products from vegetable bases: a new alternative for consuming functional food. In: RAI, V. R.; BAI, J. A. (Ed.). Beneficial microbes in fermented and functional foods. Boca Raton, London: CRC Press, 2015a. p. 207-223.

MINIM, V. P. R. Análise sensorial: estudos com consumidores. 3. ed. Viçosa, MG: UFV, 2013. 332 p.

MOREIRA, R. M. Desenvolvimento de suco misto adicionado de Lactobacillus rhamnosus GG a partir de polpa de juçara e manga ubá. 2015. Dissertação (Mestrado Profissional em Ciência e Tecnologia de Alimentos) - Instituto Federal de Educação, Ciência e Tecnologia do Sudeste de Minas Gerais, Rio Pomba.

NORATTO, G. D.; BERTOLDI, M. C.; KRENEK, K.; TALCOTT, S. T.; STRINGHETA, P. C.; MERTENSTALCOTT, S. U. Anticarcinogenic effects of polyphenolics from mango (Mangifera indica) varieties. Journal of Agriculture and Food Chemistry, München, v. 58, n. 7, p. 4104-4112, 2010.

NUALKAEKUL, S.; CHARALAMPOPOULOS, D. Survival of Lactobacillus plantarum in model solutions and fruit juices. International Journal of Food Microbiology, London, v. 146, n. 2, p. 111-117, 2011.
NUNES, J. S.; CASTRO, D. S. de; SOUSA, F. C. de; SILVA, L. M. M.; GOUVEIA, J. P. G. de. Obtenção e caracterização físico-química de polpa de jabuticaba (Myrciaria Cauliflora Berg) congelada. Revista Verde de Agroecologia e Desenvolvimento Sustentável, Mossoró, v. 9, n. 1, p. 234-237, 2014.

PERES, C. M.; PERES, C.; HERNÁNDEZ-MENDOZA, A.; MALCATA, F. X. Review on fermented plant materials as carriers and sources of potentially probiotic lactic acid bacteria - with an emphasis on table olives. Trends in Food Science \& Technology, London, v. 26, n. 1, p. 31-42, 2012.

PERRICONE, M.; BEVILACQUA, A.; ALTIERI, C.; SINIGAGLIA, M.; CORBO, M. R. Challenges for the production of probiotic fruit juices. Beverages, Basel, v. 1, n. 2, p. 95-103, 2015.

RANADHEERA, C. S.; PRASANNA, P. H. P.; VIDANARACHCHI, J. K. Fruit juice as probiotic carriers. In: ELDER, K.E. (Ed.). Fruit juices: types, nutritional composition and health benefits. New York: Nova Science Publishers, 2014. p. 1-19.

RATHORE, S.; SALMERON, I.; PANDIELLA, S. S. Production of potentially probiotic beverages using single and mixed cereal substrates fermented with lactic acid bacteria cultures. Food Microbiology, London, v. 30, n. 1, p. 239-244, 2012.

R DEVELOPMENT CORE TEAM. A language and environment for statistical computing. R Foundation for Statistical Computing. Vienna: the R Foundation for Statistical Computing, 2008. Available at: <http:// www.R-project.org.>. Accessed at: 1 nov. 2015.

RE, R.; PELEGRINI, N.; PROTEGGENTE, A.; PANNALA, A.; YANG, M.; RICEEVANS, C. Antioxidant activity applying an improved ABTS radical cátion decolorization assay. Free Radical Biology and Medicine, Bethesda, v. 26, n. 9-10, p. 1231-1237, 1999.

RICHER, R. L.; VEDAMUTHU, E. R. Milk and milk products. In: DOWNES, F. P.; ITO, K. (Ed.). Compendium of methods for the microbiological examination of foods. 4. ed. Washington: American Public Health Association - APHA, 2001. p. 483-496.

RUFINO, M. S. M.; ALVES, R. E.; BRITO, E. de.; MORAIS, S. M. de; SAMPAIO, C. G.; JIMÉNEZ, J. P.; CALIXTO, F. D. S. Metodologia científica: determinação da atividade antioxidante total em frutas pela captura do radical livre ABTS. Fortaleza: Embrapa Agroindústria Tropical, 2007. n. 128, 4 p. (Comunicado Técnico). 
SANTO, A. P. E.; PEREGO, P.; CONVERTI, A.; OLIVEIRA, M. N. Influence of food matrices on probiotic viability - a review focusing on the fruity bases. Trends in Food Science and Technology, London, v. 22, n. 7, p. 377-385, 2011.

SILVA, P. H. A.; FARIA, F. C.; TONON, B.; MOTA, S. J. D.; PINTO, V. T. Avaliação da composição química de fermentados alcoólicos de jabuticaba (Myrciaria jabuticaba). Química Nova, São Paulo, v. 31, n. 3, p. 595-600, 2008.

SINGLETON, V. L.; ROSSI, J. A. Colorimetry of total phenolics with phosphomolybdic-phosphotungstic acid reagents. American Journal of Enology and Viticulture, Davis, v. 16, n. 3, p. 144-158, 1965.

TAIZ, L.; ZEIGER, E. Fisiologia vegetal. 3. ed. Porto Alegre: Artmed, 2004. 719 p.
TEIXEIRA, N. C. Desenvolvimento, caracterização físico-química e avaliação sensorial de suco de jabuticaba (Myrciaria jaboticaba (Vell) Berg). 2011. Dissertação (Mestrado em Ciência de Alimentos) Universidade Federal de Minas Gerais, Belo Horizonte.

TRIPATHI, M. K.; GIRI, S. K. Probiotic functional foods: survival of probiotics during processing and storage. Journal of Functional Foods, St. John's, v. 9, p. 225-241, 2014.

WU, S. P.; LONGO, C.; KENNELLY, E. J. Phytochemistry and health benefits of jaboticaba, an emerging fruit crop from Brazil. Food Research International, Amsterdam, v. 54, n. 1, p. 148-159, 2013.

ZENEBON, O.; PASCUET, N. S. Métodos físicoquímicos para análise de alimentos. 4. ed. São Paulo: Instituto Adolfo Lutz, 2004. 1004 p. 
